\title{
Estimation of the Wind Energy Potential in Various North Algerian Regions
}

\author{
Mounir Alliche ${ }^{1,2} \mathbb{D}$, Redha Rebhi ${ }^{1,2}$, Noureddine Kaid $^{3} \mathbb{D}$, Younes Menni ${ }^{3, * \mathbb{D}}$, Houari Ameur $^{3} \mathbb{D}$, \\ Mustafa Inc 4,5,6**D, Hijaz Ahmad 7,8,*iD, Giulio Lorenzini ${ }^{9} \mathbb{D}_{\text {, Ayman A. Aly }}^{10}$, Sayed K. Elagan 11 \\ and Bassem F. Felemban 10 (D)
}

Citation: Alliche, M.; Rebhi, R.; Kaid, N.; Menni, Y.; Ameur, H.; Inc, M.; Ahmad, H.; Lorenzini, G.; Aly, A.A.; Elagan, S.K.; et al. Estimation of the Wind Energy Potential in Various North Algerian Regions. Energies 2021, 14, 7564. https://doi.org/ $10.3390 /$ en14227564

Academic Editor: Antonio Crespo

Received: 27 September 2021

Accepted: 6 November 2021

Published: 12 November 2021

Publisher's Note: MDPI stays neutral with regard to jurisdictional claims in published maps and institutional affiliations.

Copyright: (c) 2021 by the authors. Licensee MDPI, Basel, Switzerland. This article is an open access article distributed under the terms and conditions of the Creative Commons Attribution (CC BY) license (https:// creativecommons.org/licenses/by/ $4.0 /)$.
1 Department of Mechanical Engineering, Faculty of Technology, University of Medea, Medea 26000, Algeria; alliche.mounir@univ-medea.dz (M.A.); rebhi.redha@univ-medea.dz (R.R.)

2 LERM-Renewable Energy and Materials Laboratory, University of Medea, Medea 26000, Algeria

3 Department of Technology, University Center Salhi Ahmed Naama (Ctr. Univ. Naama), P.O. Box 66, Naama 45000, Algeria; kaid.noureddine@cuniv-naama.dz (N.K.); ameur@cuniv-naama.dz (H.A.)

4 Department of Computer Engineering, Biruni University, Istanbul 34025, Turkey

5 Department of Mathematics, Science Faculty, Firat University, Elazig 23119, Turkey

6 Department of Medical Research, China Medical University Hospital, China Medical University, Taichung 40402, Taiwan

7 Department of Basic Science, University of Engineering and Technology, Peshawar 25000, Pakistan

8 Section of Mathematics, International Telematic University Uninettuno, Corso Vittorio Emanuele II, 39, 00186 Roma, Italy

9 Department of Engineering and Architecture, University of Parma, Parco Area delle Scienze, 181/A, 43124 Parma, Italy; giulio.lorenzini@unipr.it

10 Department of Mechanical Engineering, College of Engineering, Taif University, P.O. Box 11099, Taif 21944, Saudi Arabia; aymanaly@tu.edu.sa (A.A.A.); B.felemban@tu.edu.sa (B.F.F.)

11 Department of Mathematics and Statistics, College of Sciences, Taif University, P.O. Box 11099, Taif 21944, Saudi Arabia; skhalil@tu.edu.sa

* Correspondence: menni.younes@cuniv-naama.dz (Y.M.); minc@firat.edu.tr (M.I.); hijaz555@gmail.com (H.A.)

\begin{abstract}
This investigation aims to model and assess the wind potential available in seven specific regions of North Algeria. These regions, i.e., Batna, Guelma, Medea, Meliana, Chlef, Tiaret, and Tlemcen, are known for their traditional agriculture. The wind data are obtained from the National Agency of Meteorology (NAM), and a Weibull distribution is applied. In the first part of this study, the wind potential available in these sites is assessed. Then, different models are used to estimate the wind system's annual recoverable energy for these regions. We are interested in wind pumping for possible use to meet the needs of irrigation water in rural areas. Four kinds of wind turbines are explored to determine the possibility of wind energy conversion. In addition, the effects of the heights of the pylon holding the turbines are inspected by considering four cases $(10,20,40$, and $60 \mathrm{~m}$ ). This estimation showed that the annual mean wind velocity varies from 2.48 to $5.60 \mathrm{~m} / \mathrm{s}$ at a level of $10 \mathrm{~m}$. The yearly values of Weibull parameters ( $\mathrm{k}$ and $\mathrm{c}$ ) at the studied sites varied within 1.61-2.43 and 3.32-6.20 m/s, respectively. The average wind power density ranged from 11.48 (at Chlef) to $238.43 \mathrm{~W} / \mathrm{m}^{2}$ (at Tiaret), and the monthly wind recoverable potential varied from 16.64 to $138 \mathrm{~W} / \mathrm{m}^{2}$.
\end{abstract}

Keywords: Weibull distribution; wind potential; wind pumping; wind turbines; estimation

\section{Introduction}

Over many decades of the last century, continuous industrialization yielded a considerable increase in energy consumption. This is due to the demographic growth and the intensive development of some geographical regions, especially Asia. The classical energy resources (fossil energies) may be operated for a few decades, causing a shortage of global energy in the world. Moreover, wastes from nuclear power plants pose other problems in 
pollution terms (as radioactive wastes) at the moment of the next dismantling of old power plants [1].

To satisfy the energy requirements of the present society, it is essential to discover arrangements and to broaden them. Nowadays, two lines of action are available:

(i) Reduce the utilization of energy receptors and augment the productivity of power plants by enhancing their performance;

(ii) Find and develop new sources of energy.

In the immediate future, there are inexhaustible renewable energy resources that are clean and easily exploitable. Nonetheless, a few methods for extricating the force of these assets require examination and advancements to work on their dependability, lower costs (assembling, use, and reusing), and expand their energy productivity. In this general context, our study focuses on the wind energy solution that can contribute to solving irrigation problems in addition to the solar energy vector, which seems more promising.

Wind energy frameworks convert dynamic energy (related to the development of climatic air) to more helpful types of forces, and have been utilized to provide power for water systems and processing, and since the start of the twentieth century, to produce electric energy [2-5]. Windmills for water siphoning have been introduced in numerous nations, especially the country regions. Their utilization has, nonetheless, been very restricted or non-existent in Algeria. Wind energy is changed into mechanical force by wind turbines [6-10]. This would then be able to be utilized straightforwardly for granulating and so on, or for additional transformation to create electric power [11-15]. Wind turbines can be utilized separately or in bunches called 'wind farms'. Little wind turbines called air generators can likewise be used to charge enormous batteries [16-20].

Indeed, several countries have invested in this solution, such as Germany, Spain, and France in Europe. Until 2020, wind power prevised to be installed in Europe is about 70 GW [18]. In this direction, several studies have been conducted, beginning with the determination of wind power potential of various sites in North Africa up to establishing a wind atlas for each country of this strategic region of the world [21-26]. The Maghreb countries are becoming interested in this solution; $200 \mathrm{MW}$ for 2011 in Tunisia [27], $600 \mathrm{MW}$ in Morocco [28], and $80 \mathrm{MW}$ in Algeria for 2015 [29].

Other research has been conducted to show several applications of wind energy such as rural electrification [30-32] and local electricity consumption [33], as well as its conversion to other energy carriers, i.e., pumping [34], water treatment [35], water electrolysis [36], and hydrogen storage in the longer term [37], among others, Table 1.

In Algeria, the most common renewable energy source becoming increasingly used is solar energy. A few rustic water supply plots are being fueled by sun-based electric siphon frameworks, particularly in the disengaged portions of the country. If appropriately surveyed and saddled, it is appropriate to note that wind power may be applied for irrigational cultivating and water supply.

The aim of the present work is to model and assess the wind potential available in some regions of the north of Algeria, using average daily meteorological data collected in the last decade at a standard height of $10 \mathrm{~m}$ from some meteorological stations distributed over the selected sites in the north of Algeria (National Agency of Meteorology, ONM) [38]. We investigated the wind pumping for possible use to meet the needs of excessive irrigation water in rural areas of these regions. 
Table 1. Recent applications of wind energy.

\begin{tabular}{|c|c|c|}
\hline Investigator (s) & Investigated System & Highlights \\
\hline Ahmad et al. [30] & $\begin{array}{l}\text { Wind-PV-biomass hybrid renewable } \\
\text { energy system. }\end{array}$ & $\begin{array}{l}\text { The results of the techno-economic feasibility study show that } \\
\text { hybrid power system can generate more than } 50 \mathrm{MW} \text {. }\end{array}$ \\
\hline Yahyaoui et al. [31] & Stand-alone PV-wind system. & $\begin{array}{l}\text { The approach's efficiency is demonstrated throughout the cold, } \\
\text { moderate, and hot seasons, using measured climatic data and a } \\
\text { Tunisian household power consumptions. }\end{array}$ \\
\hline Li et al. [32] & $\begin{array}{l}\text { Solar-wind-biomass off-grid hybrid } \\
\text { power system. }\end{array}$ & $\begin{array}{c}\text { The results show that a hybrid power system comprising solar, } \\
\text { wind, and biomass is a reliable and cost-effective option for } \\
\text { sustainable remote rural electrification while achieving } \\
\text { environmental benefits. }\end{array}$ \\
\hline Allouhi et al. [33] & $\begin{array}{l}\text { Hybrid PV-T/wind system with } \\
\text { thermal storage for electricity and } \\
\text { heat generation. }\end{array}$ & $\begin{array}{l}\text { Self-consumption and self-sufficiency ratios are } 90.25 \% \text { and } \\
43.08 \% \text {, respectively. }\end{array}$ \\
\hline Patwal et al. [34] & $\begin{array}{l}\text { Pumped storage hydro-thermal } \\
\text { system with wind energy } \\
\text { sources (WES). }\end{array}$ & $\begin{array}{l}\text { The impacts of WES is evident from the results of test system-III, } \\
\text { which illustrated that WES was able to reduce the total thermal } \\
\text { power generation by } 4528.85 \mathrm{MW} \text { and optimal cost by } 19.86 \% \text {. }\end{array}$ \\
\hline Jeon et al. [35] & $\begin{array}{l}\text { Self-powered electro-coagulation } \\
\text { (SPEC) system driven by a wind } \\
\text { energy harvesting triboelectric } \\
\text { nanogenerator for decentralized } \\
\text { water treatment. }\end{array}$ & $\begin{array}{c}\text { The SPEC system removes } 90 \% \text { of algae and } 97 \% \text { of organic dye } \\
\text { with self-powered treatment for } 72 \mathrm{~h} \text {. }\end{array}$ \\
\hline Bos et al. [36] & $\begin{array}{l}\text { Wind power to methanol: renewable } \\
\text { methanol production using electricity, } \\
\text { electrolysis of water, and } \mathrm{CO}_{2} \\
\text { air capture. }\end{array}$ & $\begin{array}{l}10 \mathrm{MW} \text { wind turbines can accommodate the air capture instalation } \\
\text { in the base tower. }\end{array}$ \\
\hline Maleki [37] & $\begin{array}{l}\text { Autonomous solar-wind-reverse } \\
\text { osmosis desalination systems } \\
\text { coupling battery and hydrogen } \\
\text { energy storage. }\end{array}$ & $\begin{array}{l}\text { The results showed the robustness of the energy management } \\
\text { method and proposed algorithm. }\end{array}$ \\
\hline
\end{tabular}

\section{Mathematical Tools}

\subsection{Modeling of the Wind Speed Frequency}

The following method may be applied to evaluate the distribution of the wind speed:

(i) Data acquisition from the meteorological Centers in Algeria (National Agency of Meteorology, ONM);

(ii) Isovent (or wind maple) representation of Algeria using Surfer software;

(iii) Evaluation of the future wind velocity at the turbine regions;

(iv) Evaluation of the availability of particular levels of wind velocity at given times utilizing the Weibull distribution.

The geographical coordinates of the meteorological stations are provided in Table 2.

The wind map of Algeria, which gives the isowind representation, is shown in Figure 1. This map was recently proposed by Boudia et al. [26].

\subsection{Determination of Weibull Parameters}

The wind characteristics will determine the energy amount that can be effectively extracted from wind power. To determine the properties of a site, the measures of wind speed and its direction over a long period of time are required (one to ten years).

However, previous studies in the wind field have shown that the essential feature is the Weibull statistical distribution. It was the most suitable model to evaluate the wind potential, and it is a good match with the experimental data. It successfully modeled the probability of wind speeds of wind resources [21,24,39-41]. 
Table 2. The geographical location of the selected stations (in the north of Algeria).

\begin{tabular}{cccccc}
\hline \multirow{2}{*}{ Station } & \multicolumn{2}{c}{ Latitude $(\boldsymbol{N})$} & \multicolumn{2}{c}{ Longitude $(\boldsymbol{E})$} & Elevation \\
\cline { 2 - 6 } & Deg & Min & Deg & Min & $(\mathbf{m})$ \\
\hline Batna & 35 & 38 & 4 & 50 & 1036 \\
\hline Guelma & 36 & 28 & 7 & 28 & 290 \\
\hline Medea & 36 & 16 & 2 & 45 & 881 \\
\hline Meliana & 36 & 18 & 2 & 14 & 715 \\
\hline Chlef & 36 & 12 & 1 & 20 & 143 \\
\hline Tiaret & 35 & 23 & 19 & 22 & 995 \\
\hline Tlemcen & 34 & 53 & 19 & 12 & 842 \\
\hline
\end{tabular}

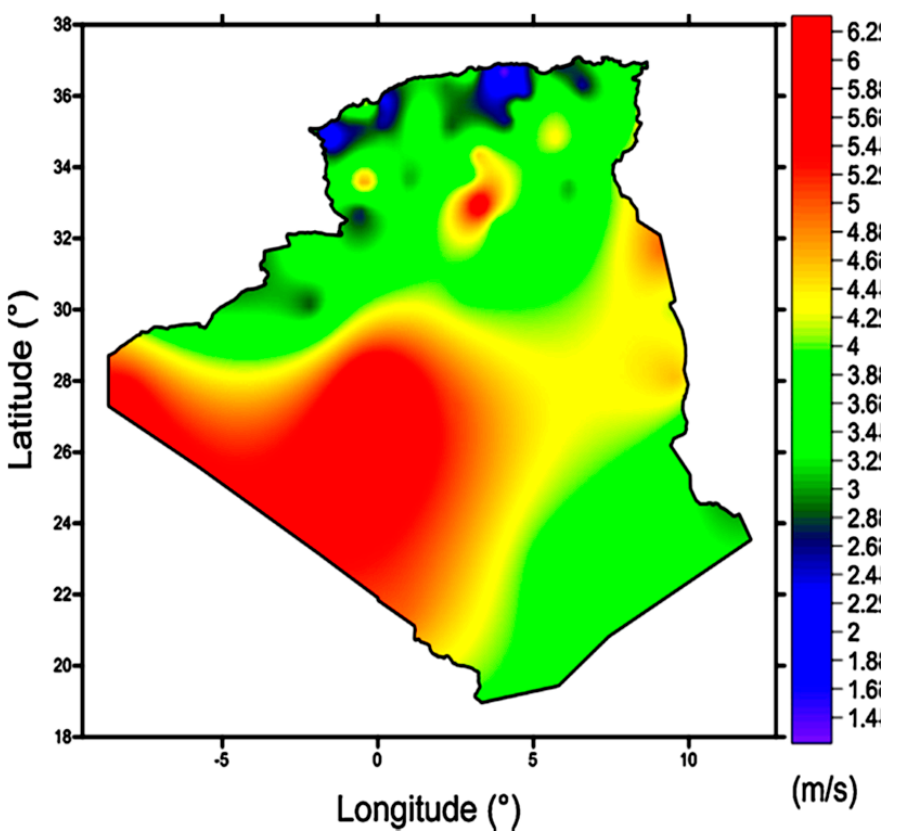

Figure 1. Wind map evaluation in Algeria at a $10 \mathrm{~m}$ height $(\mathrm{m} / \mathrm{s})$.

The Weibull probability density function is expressed as follows:

$$
f(v)=\left(\frac{k}{c}\right) \cdot\left(\frac{v}{c}\right)^{k-1} \cdot \exp \left(-\left(\frac{v}{c}\right)^{k}\right)
$$

The parameters $k$ and $c$ are the shape factor (dimensionless) and the scaling factor in $\mathrm{m} / \mathrm{s}$. Usually, the shape factor characterizes the distribution of the wind. The scaling factor characterizes the average wind speed $(\mathrm{m} / \mathrm{s})$.

There are several methods for determining the factors $k$ and $c$. For example:

(i) The least mean squares method;

(ii) The maximum likelihood method;

(iii) The process of standard deviation.

In this study, we applied the latter method. It is based on the computing of the variance and the mean velocity $[40,42]$ :

$$
\begin{aligned}
& k=\left(\frac{\sigma}{\bar{v}}\right)^{-1.086} \\
& c=\frac{\bar{v}}{\Gamma\left(1+\frac{1}{k}\right)}
\end{aligned}
$$


where $\Gamma$ is the gamma function for exponential distribution defined for a variable $z$ given by the following expression:

$$
\Gamma(z)=\int_{0}^{\infty} \exp (-t) \cdot t^{z-1} d t
$$

\subsection{Estimation of the Annual Wind Potential}

The average power available on a given site per unit time and surface of a wind turbine is expressed by the following:

$$
\overline{P_{\text {dis }}}=\frac{1}{2} \rho \overline{v^{3}}
$$

where $\rho$ is the density of air equal to $1.25 \mathrm{~kg} / \mathrm{m}^{3}$ at the temperature and pressure conditions of $\mathrm{T}=20^{\circ} \mathrm{C}$ and $P=1 \mathrm{~atm}$, respectively, and the cubic average speed of wind can be calculated by the following expression $[15,39]$ :

$$
\overline{v^{3}}=c^{3} \cdot \Gamma\left(1+\frac{3}{k}\right)
$$

However, studies have shown that this power supply is not fully utilized at the wheel of the turbine. Using Betz's law, the power is recovered up to $59 \%$ of the energy available [21,39]:

$$
\overline{P_{\text {recup }}}=\frac{16}{27} \overline{P_{\text {dis }}}
$$

\section{Findings and Analysis}

In our case, we want to treat the North Region of Algeria and, especially, the cited towns in Table 2 (Batna, Guelma, Medea, Meliana, Chlef, Tiaret, and Tlemcen) as a first step, and then generalize the study in future work to other sites in the north of Algeria, particularly the isolated regions of these departments. The processed data are spread over the last fifteen years, from 2007 to 2020.

\subsection{Distribution of Wind Speed}

Figure 1 shows the wind map evaluation in Algeria at a $10 \mathrm{~m}$ height $(\mathrm{m} / \mathrm{s})$ proposed by Boudia et al. [26]. The north of Algeria is relatively characterized by a low wind speed. Particularly, for the selected sites in this work, the wind speed reaches $5.5 \mathrm{~m} / \mathrm{s}$ in the Tiaret site, and the lower values are 2.90 and 3.31 in the Medea and Chlef sites, respectively, as

\begin{tabular}{|c|c|c|c|c|c|}
\hline \multirow{2}{*}{ Station } & \multicolumn{2}{|c|}{ Weibull Parameters } & \multirow{2}{*}{$\frac{v}{(\mathrm{~m} / \mathrm{s})}$} & \multirow{2}{*}{$\frac{P_{\text {disp }}}{\left(\mathrm{W} / \mathrm{m}^{2}\right)}$} & \multirow{2}{*}{$\begin{array}{l}P_{\text {recup }} \\
\left(\mathrm{W} / \mathrm{m}^{2}\right)\end{array}$} \\
\hline & $k$ & $c(\mathrm{~m} / \mathrm{s})$ & & & \\
\hline Batna & 1.61 & 4.91 & 4.40 & 130.92 & 77.24 \\
\hline Guelma & 2.10 & 4.80 & 4.30 & 87.49 & 51.62 \\
\hline Medea & 1.90 & 3.32 & 2.90 & 46.18 & 27.25 \\
\hline Meliana & 2.43 & 5.11 & 4.53 & 72.37 & 42.70 \\
\hline Chlef & 1.95 & 3.37 & 3.31 & 28.20 & 16.64 \\
\hline Tiaret & 1.72 & 6.20 & 5.50 & 233.92 & 138.01 \\
\hline Tlemcen & 2.02 & 4.29 & 3.80 & 64.92 & 38.30 \\
\hline
\end{tabular}
shown in Table 3. We note here that the wind speed measured values present an important fluctuation for different years.

Table 3. Weibull parameters and available powers in selected sites. 
For example, Figure 2 shows the monthly variation in average wind speed for the site of Medea for three years $(2016,2018$, and 2020). This site has had a maximum wind speed average of about $4.20 \mathrm{~m} / \mathrm{s}$ and a minimum speed of about $2.10 \mathrm{~m} / \mathrm{s}$ during the last ten years. However, measures taken on site show peaks reaching $29.00 \mathrm{~m} / \mathrm{s}$ in January 2009 (Meteorological Station of Medea, 2009) [38].

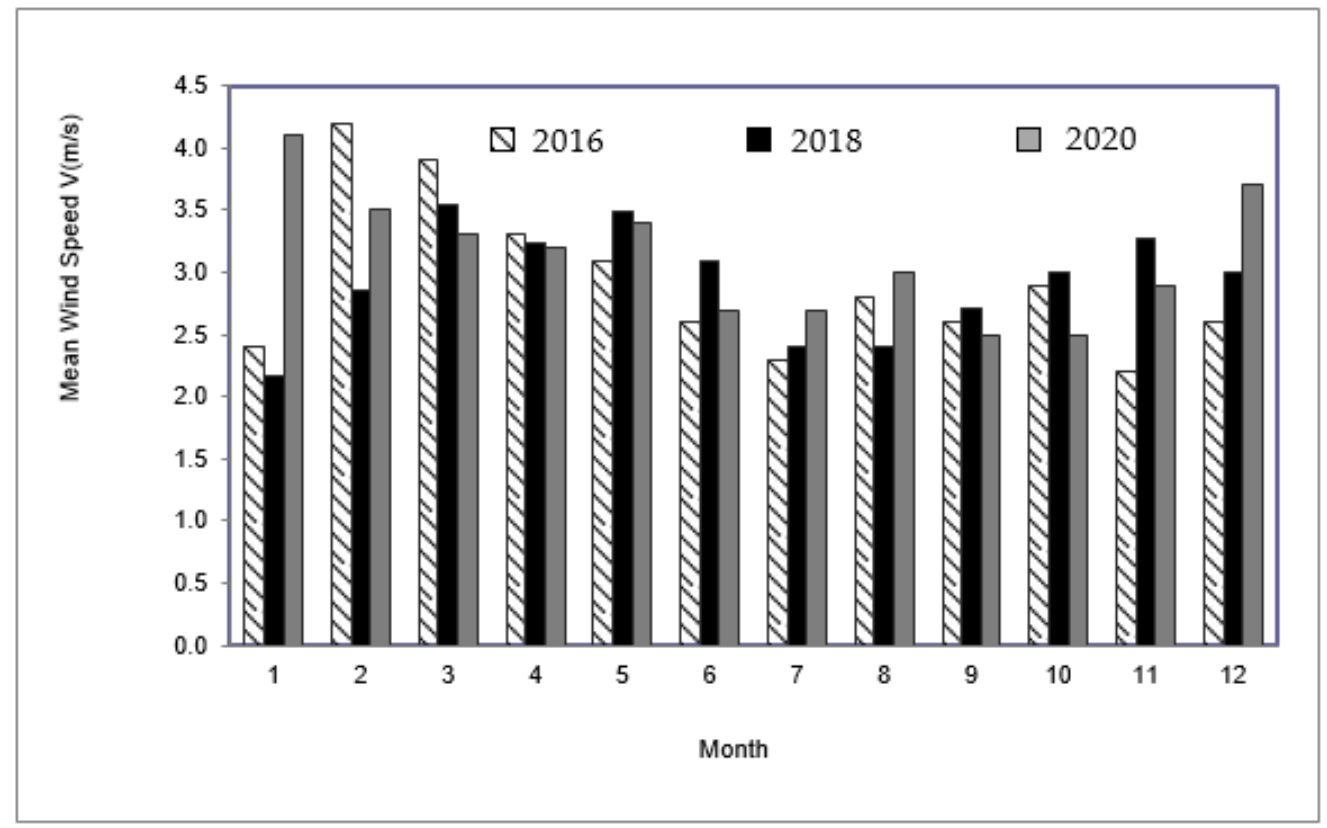

Figure 2. Monthly changes in the average wind velocity for the site of Medea (at $z=10 \mathrm{~m}$ for three years).

The Weibull distribution of average wind speeds in the case of Medea location is illustrated in Figure 3. It shows that $25 \%$ of the velocities are accumulated between 2 and $3 \mathrm{~m} / \mathrm{s}$, while the interval of the density function extends up to $9 \mathrm{~m} / \mathrm{s}$.

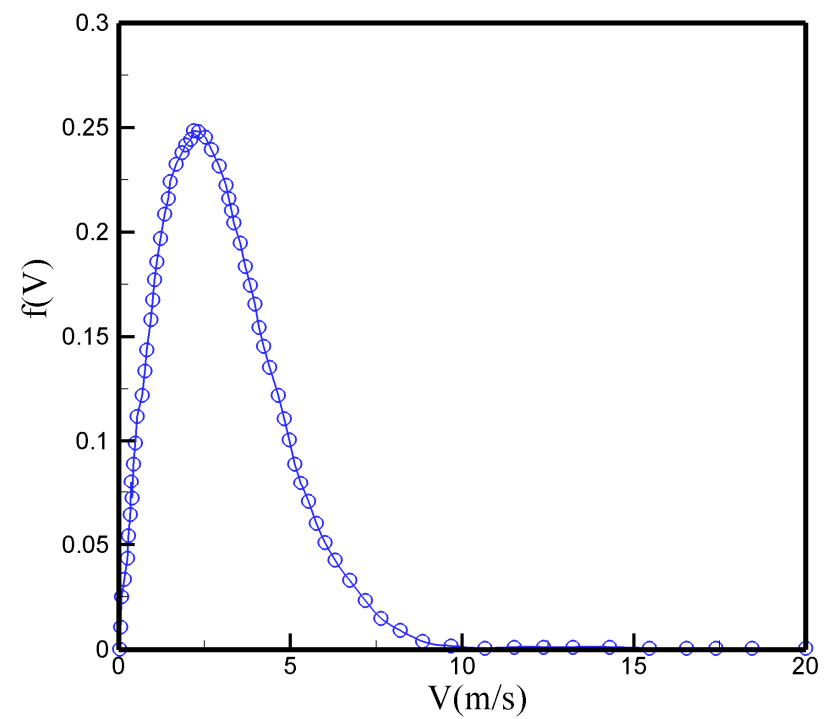

Figure 3. The Weibull probability function density for the site of Medea (at $z=10 \mathrm{~m}$ ).

Figure 4 gives the Weibull distribution of average wind speeds and mean power for the other selected sites. It can be seen that Tiaret, Batna, and Meliana have the more significant wind power potential in the north of Algeria. Table 3 illustrates this observation and quantifies the maximum mean power in Tiaret of about $230 \mathrm{~W} / \mathrm{m}^{2}$. The lower value 
is about $28 \mathrm{~W} / \mathrm{m}^{2}$ in Chlef. The variation of wind speed with altitude may be calculated as follows:

$$
v_{2}=v_{1} \cdot\left(\frac{Z_{2}}{Z_{1}}\right)^{\alpha}
$$

where $v_{1}$ and $v_{2}$ are the calculated values of wind speed at height $Z_{1}$ and $Z_{2}$, respectively, and $\alpha$ is the wind speed power law exponent. This latter is given by the following [43]:

$$
\alpha=\frac{1}{\operatorname{Ln}\left(\frac{\bar{Z}}{Z_{0}}\right)}-\left\{\frac{0.0881}{1-0.0881 \operatorname{Ln}\left(\frac{Z_{1}}{10}\right)}\right\} \operatorname{Ln}\left(\frac{v_{1}}{6}\right)
$$

with

$$
\bar{Z}=\exp \left(\operatorname{Ln}\left(Z_{1}\right)+\operatorname{Ln}\left(Z_{2}\right)\right) / 2
$$

and $Z_{0}$ is the roughness of the site.

For Medea, we take $0.01 \mathrm{~m}$ as the roughness value. The value of the power law exponent $\alpha$ is about 0.23 . Hence, we estimate the wind speed at $20 \mathrm{~m}, 40 \mathrm{~m}$, and $60 \mathrm{~m}$ of height using Equation (8), as illustrated in Figure 5. The wind speed reaches the range 3.2 to $5.5 \mathrm{~m} / \mathrm{s}$ at $60 \mathrm{~m}$.

\subsection{Determination of the Recovered Power by Year}

Table 3 shows the annual mean wind power energy available and recoverable at the selected sites. For example, it shows a low recovered power of approximately $27.25 \mathrm{~W} / \mathrm{m}^{2}$ at Medea compared with the other sites cited in this table or those found in sites in the High Plains cited by Merzouk [39]. However, the result found here is comparable to that found for the site of Chlef.

On the other hand, for the site of Medea, examination of the distribution of monthly available power shows that we can operate a power ranging from 20 to $45 \mathrm{~W} / \mathrm{m}^{2}$ for a period of eight months per year (Figure 6). The minimum value is about $10 \mathrm{~W} / \mathrm{m}^{2}$ in January.

\subsection{Wind Turbine Selection}

A huge assortment of wind generators is created by many methods on the planet. The majority of these breeze turbines are small or medium machines providing an electric force somewhere in the range of 0.25 and $100 \mathrm{~kW}$.
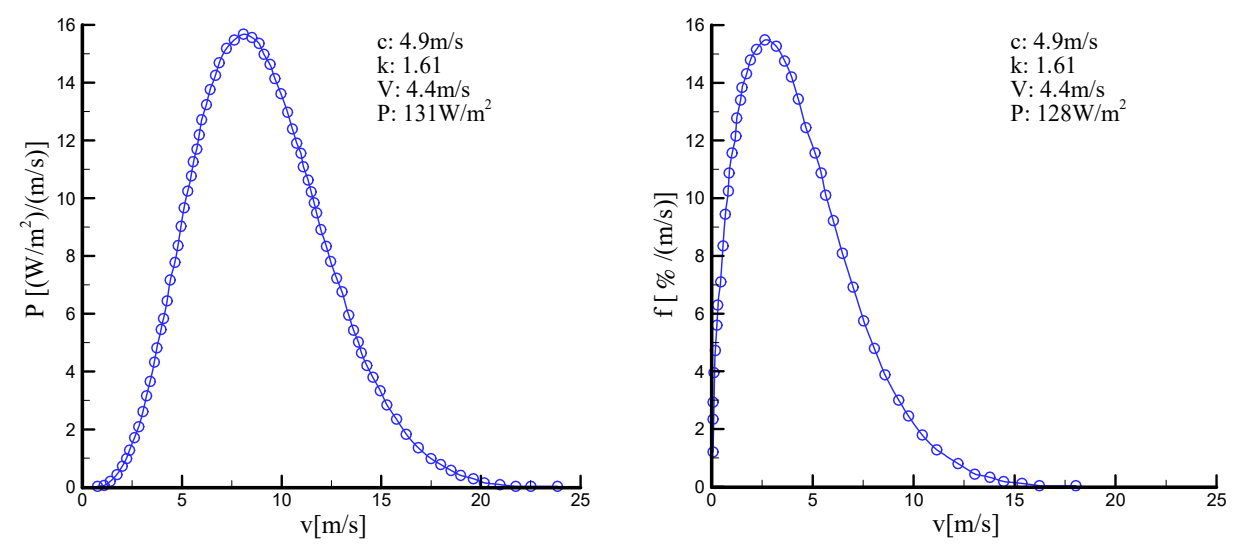

(a) Batna

Figure 4. Cont. 

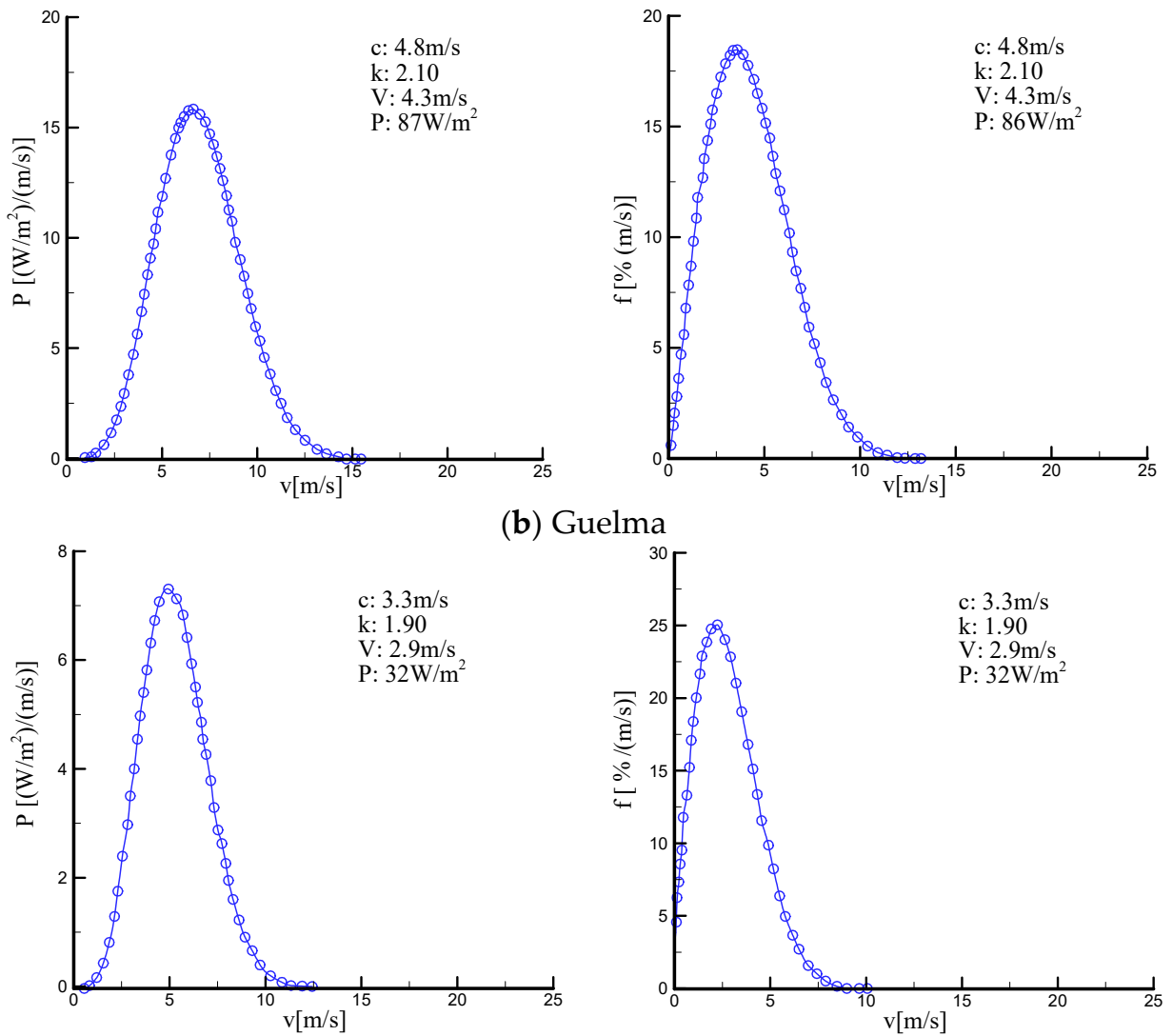

(c) Medea
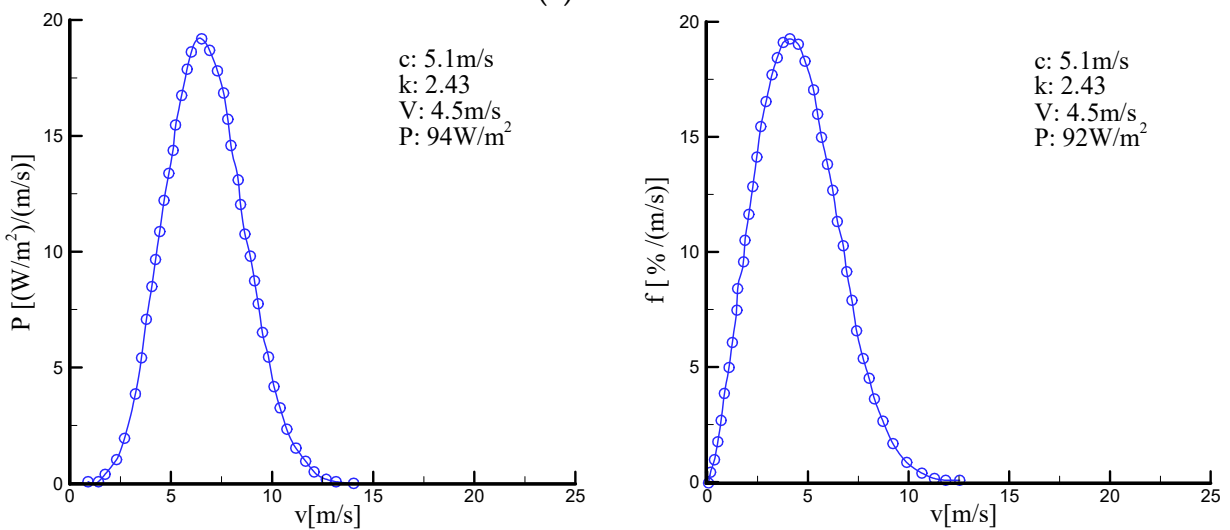

(d) Meliana
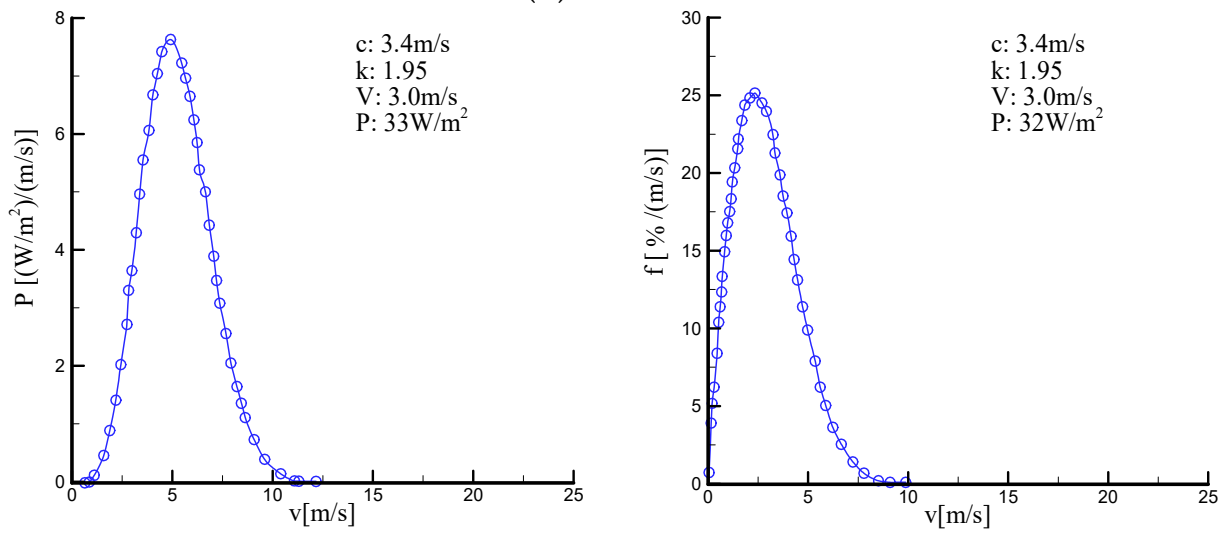

(e) Chlef

Figure 4. Cont. 

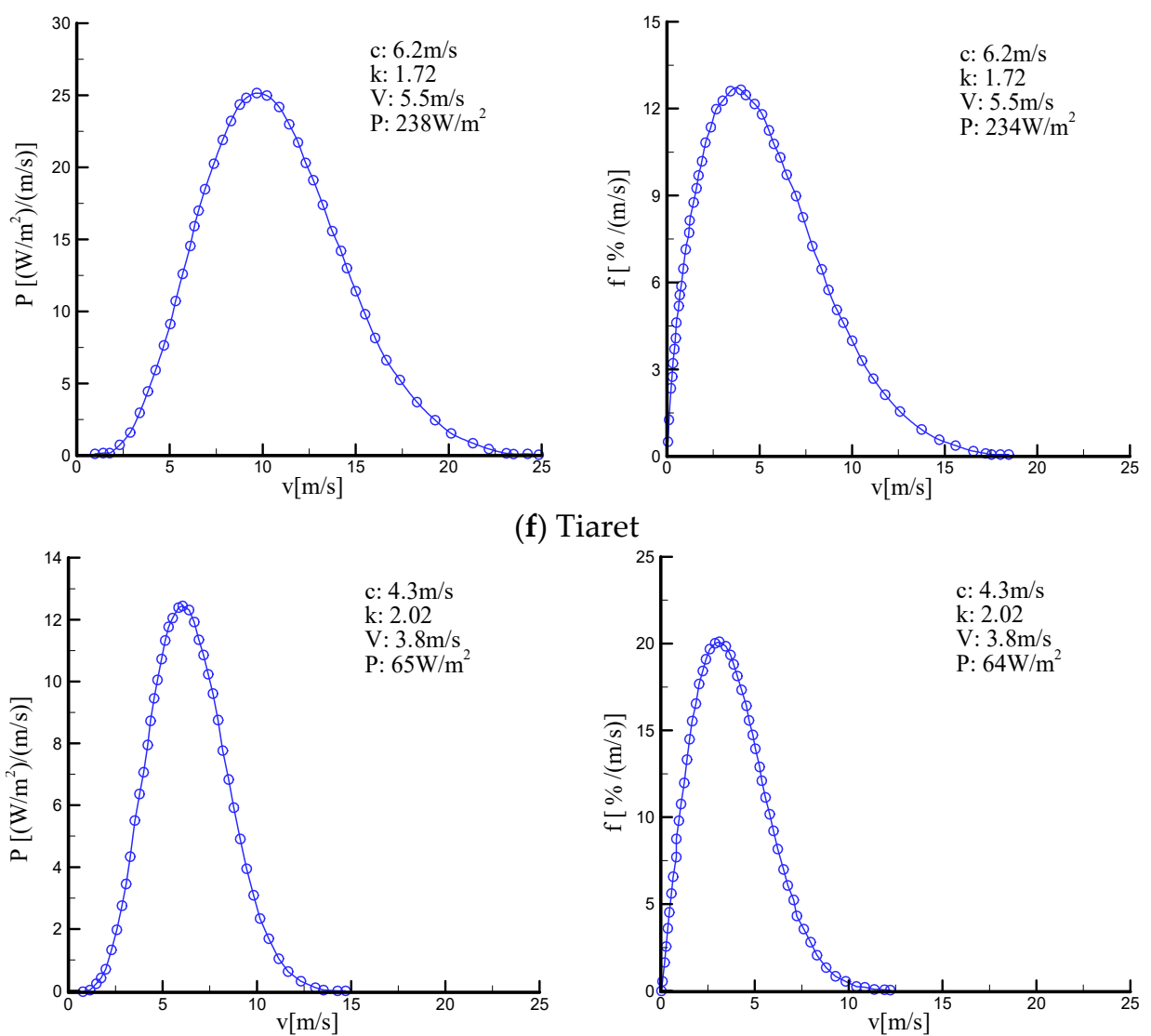

(g) Tlemcen

Figure 4. The Weibull probability function and mean wind power for the selected sites.

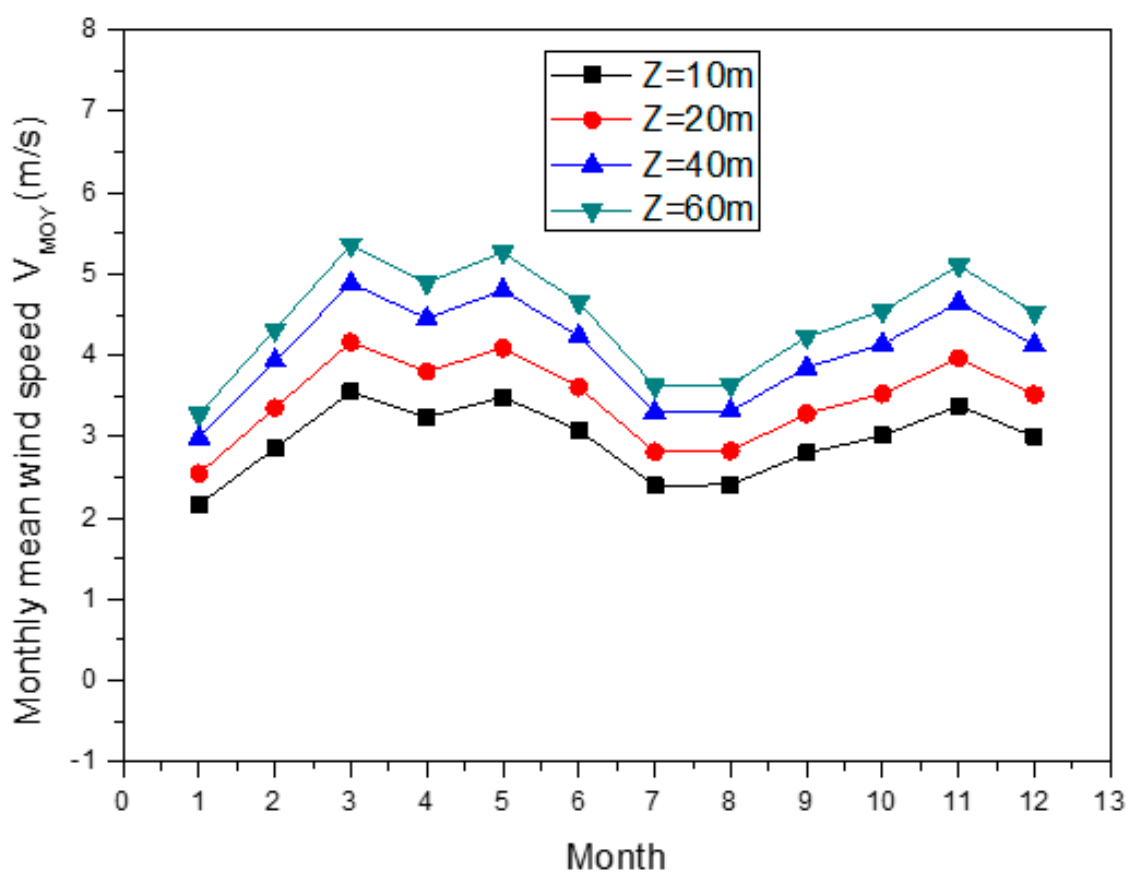

Figure 5. Wind profile for different heights in Medea $(z=10,20,40$, and $60 \mathrm{~m})$. 


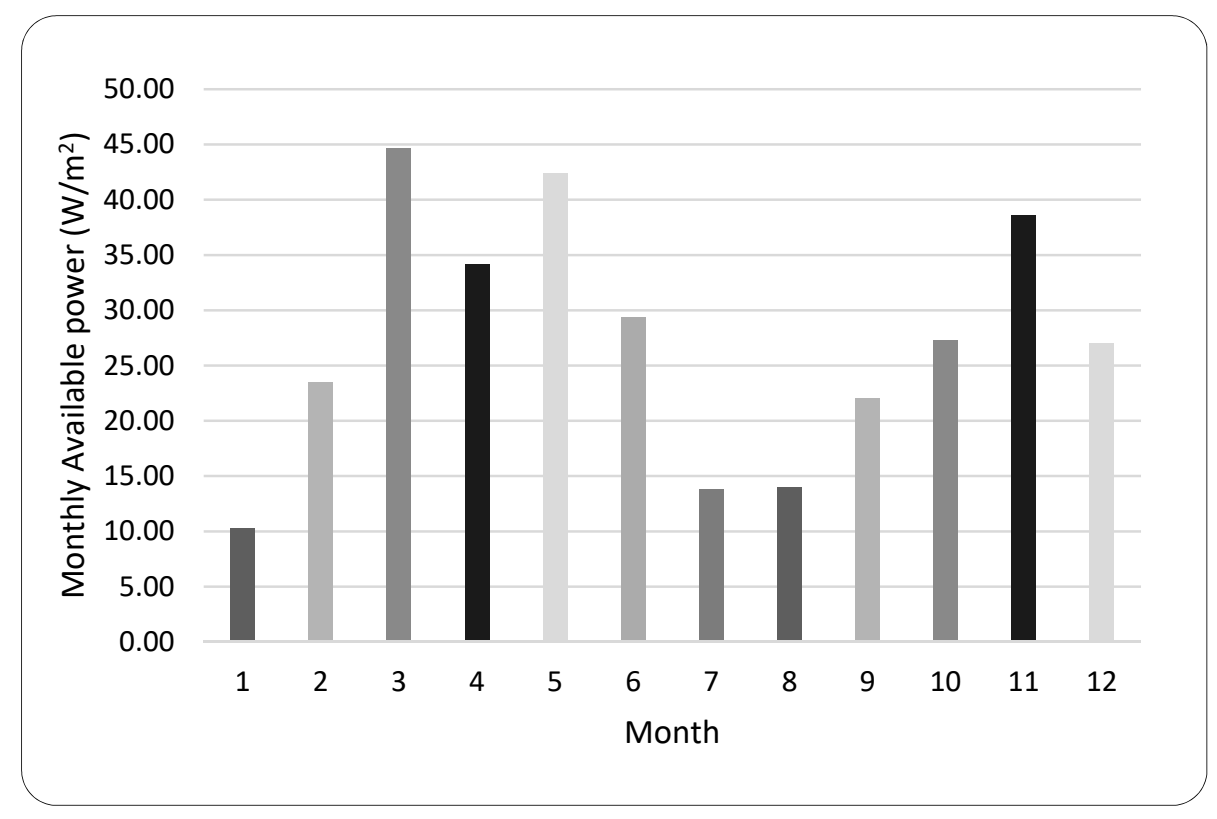

Figure 6. Distribution of available monthly power in the site of Medea (at $z=10 \mathrm{~m}$ ).

Taking into account the socio-geographical conditions and wind potential of the region of Medea, four types of wind turbines have been selected and characterized by their satisfying efficiency and acceptable cost (Table 4). It is noted that all these wind turbines have a cut-in wind velocity smaller than the mean wind velocity of the site of Medea (about $3.13 \mathrm{~m} / \mathrm{s})$. Table 4 shows the main features of the chosen wind turbines; precisely the helix diameter $(D)$, the nominal speed $\left(v_{\mathrm{n}}\right)$, and nominal power $\left(P_{\mathrm{n}}\right)$. All these generators have three blades.

Table 4. Main characteristics of the four wind generators.

\begin{tabular}{cccccc}
\hline Type & Manufacture & $\boldsymbol{D}(\mathbf{m})$ & $\boldsymbol{v}_{\mathbf{n}}(\mathbf{m} / \mathbf{s})$ & $\boldsymbol{P}_{\mathbf{n}}(\mathbf{k W})$ & Cut-in Speed $(\mathbf{m} / \mathbf{s})$ \\
\hline Bergey Excel-S & Bergy Co (Santa Rosa, CA, USA) & 6.7 & 16.0 & 10 & 3 \\
Bergey XL1 & Bergy Co (USA) & 2.5 & 18.0 & 1 & 2.5 \\
Fuhrlander FL & Fuhrlander (Libenscheid, Germany) & 21 & 11.5 & 100 & 3 \\
Enercon E33 & Enercon (Aurich, Germany) & 33.4 & 13.0 & 335 & 3 \\
\hline
\end{tabular}

The monthly power produced by the four selected wind turbines shows two families of turbines; small ones (Bergey Excel-S and Bergey XL1) delivering about 0.13 to $1.00 \mathrm{~kW}$ and big ones (Fuhrlander FL and Enercon E33) reaching $23.86 \mathrm{~kW}$ per month (Figure 7).

On the other hand, using those small wind turbines (Bergey Excel-S and Bergey XL1) for water pumping purposes permits us to pump about $15 \times 10^{3} \mathrm{~m}^{3}$ with the first one and $1.05 \times 10^{3} \mathrm{~m}^{3}$ with the second one for a height of $50 \mathrm{~m}$ (Figure 8).

However, in these regions where solar energy is abundant, small wind turbines can be coupled with properly sized photovoltaic conversion systems. This kind of wind turbine can usefully be employed to pump water, irrigate cultivated fields or oasis, and feed houses or farms with electricity in such regions. The smaller wind turbines contribute to supplying houses with electricity, and then replace diesel engines as auxiliary sources. 


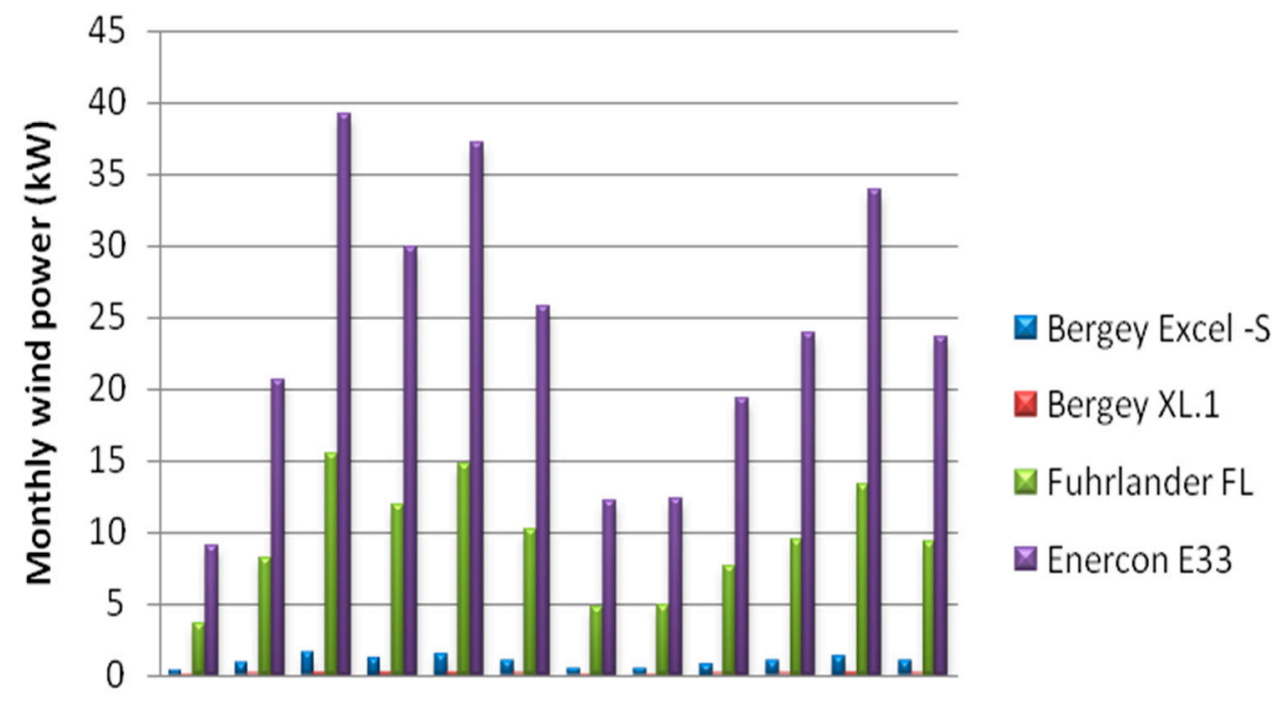

\section{$\begin{array}{llllllllllll}1 & 2 & 3 & 4 & 5 & 6 & 7 & 8 & 9 & 10 & 11 & 12\end{array}$ \\ Month}

Figure 7. Monthly wind power produced by the four wind turbines in Medea.

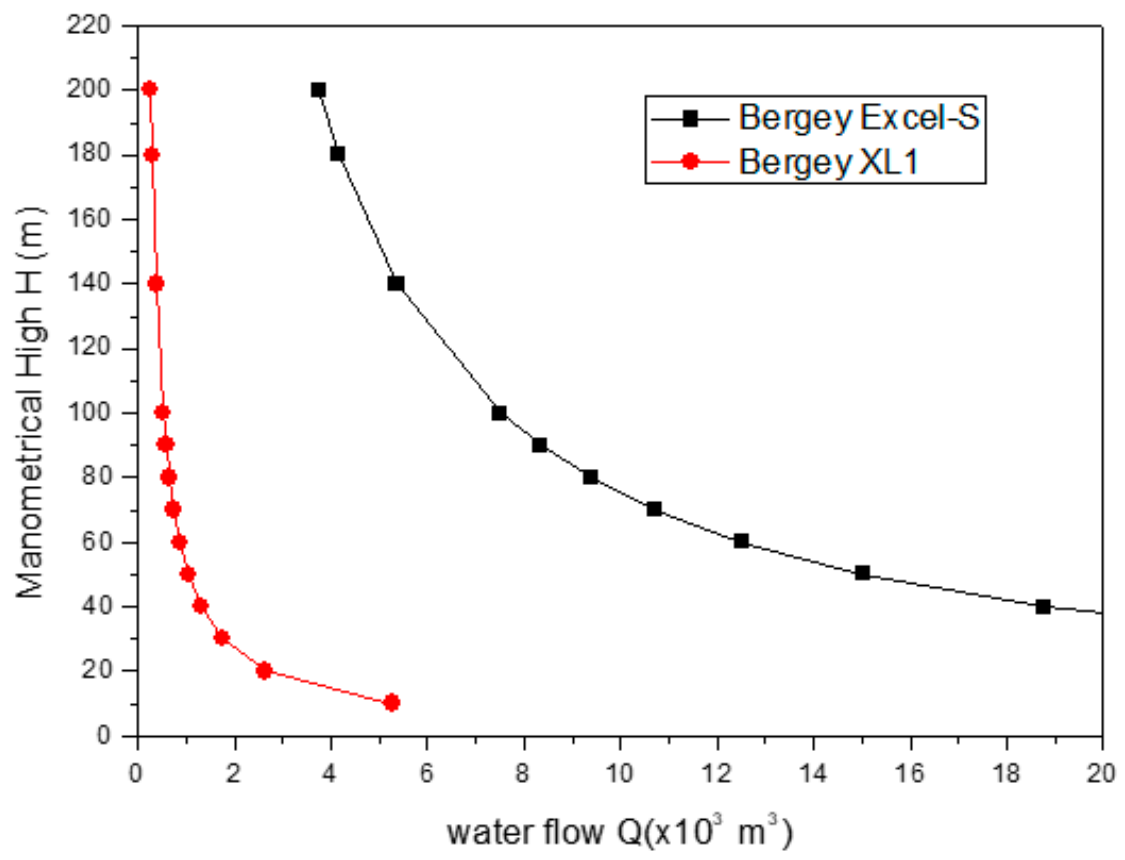

Figure 8. Daily water pumping for two wind turbines.

\section{Conclusions}

The following points were found during this research to assess the wind potential in various regions of the north of Algeria:

- At a height of $10 \mathrm{~m}$, the yearly mean wind velocity ranges from 2.48 to $5.60 \mathrm{~m} / \mathrm{s}$. The chosen locations have a lower wind character, i.e., $v_{\text {mean }}=3.13 \mathrm{~m} / \mathrm{s}$.

- At the study stations, the annual values of Weibull parameters ( $k$ and $c$ ) ranged from 1.61 to 2.43 and 3.32 to $6.20 \mathrm{~m} / \mathrm{s}$, respectively.

- $\quad$ The mean wind power density varied from 11.48 at Chlef to $238.43 \mathrm{~W} / \mathrm{m}^{2}$ at Tiaret.

- $\quad$ The monthly wind recoverable potential varied from 16.64 to $138 \mathrm{~W} / \mathrm{m}^{2}$.

Wind power, on the other hand, can be considered in the north of Algeria to satisfy power demand thanks to its renewability and sustainability, despite the fact that the wind 
speed is rather low. So, using its monthly wind recoverable potential of around $27.25 \mathrm{~W} / \mathrm{m}^{2}$ and an annual value of about $3.27 \mathrm{~kW} / \mathrm{m}^{2}$ (in Medea, for example) for pumping at modest drills, it may be subjected to a practical examination.

Furthermore, it would be more fascinating to investigate many regions of these departments in order to identify ideals places for the construction of wind power plants to generate electricity.

Author Contributions: Conceptualization, M.A.; methodology, R.R.; software, N.K.; validation, M.A.; formal analysis, R.R.; investigation, Y.M.; resources, H.A. (Houari Ameur); data curation, M.I.; writing-original draft preparation, H.A. (Hijaz Ahmad) and G.L.; writing-review and editing, A.A.A., S.K.E., B.F.F. and Y.M.; Funding, A.A.A., S.K.E. and B.F.F. All authors have read and agreed to the published version of the manuscript.

Funding: Taif University Researchers Supporting Project number (TURSP-2020/260), Taif University, Taif, Saudi Arabia.

Institutional Review Board Statement: Institutional Review Board Statement and approval number are not applicable.

Informed Consent Statement: No informed consent statement is required for this study.

Data Availability Statement: All data are available in the manuscript.

Acknowledgments: I would like to thank Taif University Researchers Supporting Project number (TURSP-2020/260), Taif University, Taif, Saudi Arabia.

Conflicts of Interest: The authors declare no conflict of interest.

\section{References}

1. Abderrahim, A.; Boudia, M.M.; Ghellai, N.; Menni, Y.; Ameur, H. Determination of the wind potential in some regions of Algeria. Iran. (Iran.) J. Energy Environ. 2020, 11, 193-197.

2. Barrows, S.E.; Homer, J.S.; Orrell, A.C. Valuing wind as a distributed energy resource: A literature review. Renew. Sustain. Energy Rev. 2021, 152, 111678. [CrossRef]

3. Peng, X.; Liu, Z.; Jiang, D. A review of multiphase energy conversion in wind power generation. Renew. Sustain. Energy Rev. 2021, 147, 111172. [CrossRef]

4. Barra, P.H.A.; de Carvalho, W.C.; Menezes, T.S.; Fernandes, R.A.S.; Coury, D.V. A review on wind power smoothing using high-power energy storage systems. Renew. Sustain. Energy Rev. 2021, 137, 110455. [CrossRef]

5. de Siqueira, L.M.S.; Peng, W. Control strategy to smooth wind power output using battery energy storage system: A review. J. Energy Storage 2021, 35, 102252. [CrossRef]

6. Chidambaram, P.K.; Thamilarasan, K.; Kumar, J.B.; Mary, L.A. A review on turbines in power production using wind and hydro energy. Mater. Today Proc. 2021. [CrossRef]

7. Hevia-Koch, P.; Ladenburg, J. Where should wind energy be located? A review of preferences and visualisation approaches for wind turbine locations. Energy Res. Soc. Sci. 2019, 53, 23-33. [CrossRef]

8. Igwemezie, V.; Mehmanparast, A.; Kolios, A. Current trend in offshore wind energy sector and material requirements for fatigue resistance improvement in large wind turbine support structures-A review. Renew. Sustain. Energy Rev. 2019, 101, 181-196. [CrossRef]

9. Zhu, W.J.; Shen, W.Z.; Barlas, E.; Bertagnolio, F.; Sørensen, J.N. Wind turbine noise generation and propagation modeling at DTU Wind Energy: A review. Renew. Sustain. Energy Rev. 2018, 88, 133-150. [CrossRef]

10. Swenson, L.; Gao, L.; Hong, J.; Shen, L. An efficacious model for predicting icing-induced energy loss for wind turbines. Appl. Energy 2022, 305, 117809. [CrossRef]

11. Singh, S.; Fozdar, M.; Malik, H.; Fernandez Moreno, M.D.V.; Garcia Marquez, F.P. Influence of wind power on modeling of bidding strategy in promising power market with a modified gravitational search algorithm. Appl. Sci. 2021, 11, 4438. [CrossRef]

12. Oh, E. Reinforcement-learning-based virtual energy storage system operation strategy for wind power forecast uncertainty management. Appl. Sci. 2020, 10, 6420. [CrossRef]

13. Wang, Y.; Zou, R.; Liu, F.; Zhang, L.; Liu, Q. A review of wind speed and wind power forecasting with deep neural networks. Appl. Energy 2021, 304, 117766. [CrossRef]

14. Li, L.L.; Shen, Q.; Tseng, M.L.; Luo, S. Power system hybrid dynamic economic emission dispatch with wind energy based on improved sailfish algorithm. J. Clean. Prod. 2021, 316, 128318. [CrossRef]

15. Celik, A.N. Energy output estimation for small-scale wind power generators using Weibull-representative wind data. J. Wind Eng. Ind. Aerodyn. 2003, 91, 693-707. [CrossRef] 
16. Balasubramanian, K.; Thanikanti, S.B.; Subramaniam, U.; Sudhakar, N.; Sichilalu, S. A novel review on optimization techniques used in wind farm modelling. Renew. Energy Focus 2020, 35, 84-96. [CrossRef]

17. Tao, S.; Xu, Q.; Feijóo, A.; Zheng, G.; Zhou, J. Nonuniform wind farm layout optimization: A state-of-the-art review. Energy 2020, 209, 118339. [CrossRef]

18. Kheirabadi, A.C.; Nagamune, R. A quantitative review of wind farm control with the objective of wind farm power maximization. J. Wind Eng. Ind. Aerodyn. 2019, 192, 45-73. [CrossRef]

19. Rippel, D.; Jathe, N.; Becker, M.; Lütjen, M.; Szczerbicka, H.; Freitag, M. A Review on the planning problem for the installation of offshore wind farms. IFAC-Pap. Online 2019, 52, 1337-1342. [CrossRef]

20. Shakoor, R.; Hassan, M.Y.; Raheem, A.; Wu, Y.K. Wake effect modeling: A review of wind farm layout optimization using Jensen's model. Renew. Sustain. Energy Rev. 2016, 58, 1048-1059. [CrossRef]

21. Benmedjahed, M.; Maouedj, R.; Mouhadjer, S.; Menni, Y.; Ameur, H.; Dahbi, A.; Saba, D.; Touahri, T. Analysis of the wind resources in Saharan Atlas of Algeria: Adrar region as a case study. Iran. (Iran.) J. Energy Environ. 2021, 12, 155-160.

22. Mederreg, D.; Salmi, M.; Rachid, M.; Ahmad, H.; Lorenzini, G.; Menni, Y.; Ameur, H. Assessment of the resources of wind energy in various regions of Algeria. Int. J. Sustain. Dev. Plan. 2021, 16, 641-650. [CrossRef]

23. Abderrahim, A.; Ghellai, N.; Bouzid, Z.; Menni, Y. Wind energy resource assessment in south western of Algeria. Math. Model. Eng. Probl. 2019, 6, 157-162. [CrossRef]

24. Merzouk, N.K. Algeria Wind Map-Preliminary Results. Renew. Energy Rev. (Rev. Des Energ. Renouvelable) Valoris. 1999, 2, $209-214$.

25. Ettoumi, F.Y. Renewable Energy Resources in Algeria. Ph.D. Thesis, University of Science and Technology Houari Boumediene, Bab Ezzouar, Algeria, 2002.

26. Boudia, S.M.; Benmansour, A.; Hellal, M.A.T. Wind resource assessment in Algeria. Sustain. Cities Soc. 2016, 22, 171-183. [CrossRef]

27. Oumalli, A.; Baccari, N. Wind Energy Development in Tunisia. In Proceedings of the Wind Energy and Development Dialogue, Berlin, Germany, 8-12 October 2007.

28. Taya, B.; Chaguer, L. Energie éolienne au Maroc. In Proceedings of the Congrès International FIER, Tetouan, Marocco, 8-10 May 2002.

29. Chitour, C.E. Global energy balance and forecast for 2030: The place of renewable energies. In Proceedings of the 1st Mediterranean Seminar on Wind Energy, Bou-Ismail, Tipaza, Algeria, 11-12 April 2010.

30. Ahmad, J.; Imran, M.; Khalid, A.; Iqbal, W.; Ashraf, S.R.; Adnan, M.; Ali, S.F.; Khokhar, K.S. Techno economic analysis of a wind-photovoltaic-biomass hybrid renewable energy system for rural electrification: A case study of Kallar Kahar. Energy 2018, 148, 208-234. [CrossRef]

31. Yahyaoui, I.; Yahyaoui, A.; Chaabene, M.; Tadeo, F. Energy management for a stand-alone photovoltaic-wind system suitable for rural electrification. Sustain. Cities Soc. 2016, 25, 90-101. [CrossRef]

32. Li, J.; Liu, P.; Li, Z. Optimal design and techno-economic analysis of a solar-wind-biomass off-grid hybrid power system for remote rural electrification: A case study of west China. Energy 2020, 208, 118387. [CrossRef]

33. Allouhi, A. A novel grid-connected solar PV-thermal/wind integrated system for simultaneous electricity and heat generation in single family buildings. J. Clean. Prod. 2021, 320, 128518. [CrossRef]

34. Patwal, R.S.; Narang, N. Optimal generation scheduling of pumped storage hydro-thermal system with wind energy sources. Appl. Soft Comput. 2020, 93, 106345. [CrossRef]

35. Jeon, S.B.; Kim, S.; Park, S.J.; Seol, M.L.; Kim, D.; Chang, Y.K.; Choi, Y.K. Self-powered electro-coagulation system driven by a wind energy harvesting triboelectric nanogenerator for decentralized water treatment. Nano Energy 2016, 28, 288-295. [CrossRef]

36. Bos, M.J.; Kersten, S.R.A.; Brilman, D.W.F. Wind power to methanol: Renewable methanol production using electricity, electrolysis of water and $\mathrm{CO}_{2}$ air capture. Appl. Energy 2020, 264, 114672. [CrossRef]

37. Maleki, A. Design and optimization of autonomous solar-wind-reverse osmosis desalination systems coupling battery and hydrogen energy storage by an improved bee algorithm. Desalination 2018, 435, 221-234. [CrossRef]

38. Base de Données des Vitesses du Vent 2007-2015; Station Météorologique de Médéa, Office National de Météorologie: Médéa, Algeria, 2015.

39. Merzouk, N.K. Evaluation of the Wind Energy Deposit-Contribution to the Determination of the Vertical Profile of the Wind Speed in Algeria. Ph.D. Thesis, Université de Tlemcen, Chetouane, Algeria, 2006.

40. Bousalem, S.; Seddini, A.; Benyoucef, B. Optimization of the efficiency of a wind pumping system. In Congrès Comptes'2K7, Energie et Environnement; ENSA: Agadir, Marocco, 2007.

41. Mohammadi, K.; Alavi, O.; Mostafaeipour, A.; Goudarzi, N.; Jalilvand, M. Assessing different parameters estimation methods of Weibull distribution to compute wind power density. Energy Conv. Manag. 2016, 108, 322-335. [CrossRef]

42. Pavia, E.G.; O'Brien, J.J. Weibull statistics of wind speed over the ocean. J. Appl. Meteorol. Climatol. 1986, 25, 1324-1332. [CrossRef]

43. Mikhail, A.S.; Justus, C.G. Comparison of height extrapolation models and sensitivity analysis. Wind Eng. 1981, 5, 91-107. 